\title{
The Levels of Soluble CD40 Ligand and C-Reactive Protein in Normal Weight, Overweight and Obese People
}

Ilkay Tugba Unek, MD; Firat Bayraktar, MD; Dilek Solmaz, MD; Hulya Ellidokuz, MD; Ali Riza Sisman, MD; Faize Yuksel; and Sena Yesil, MD

\begin{abstract}
Objective: Obesity has been suggested as an independent risk factor for cardiovascular disease. Increasing evidence shows that engagement of soluble CD40 ligand (sCD40L) with its receptor plays a crucial role in the pathogenesis of atherosclerosis. The aim of the present study was to test whether obesity is associated with low-grade systemic inflammation as measured by serum high-sensitive C-reactive protein (hsCRP) and sCD40L concentration.
\end{abstract}

Methods: Serum hsCRP and sCD40L concentrations were measured in 148 nondiabetic people. The participants were divided into three groups depending upon their body mass index (BMI) levels: Group I (normal weight), BMI<25 kg/m²; Group 2 (overweight), BMI $25 \mathrm{~kg} / \mathrm{m}^{2}$ to $29.9 \mathrm{~kg} / \mathrm{m}^{2}$; and Group 3 (obese), $\mathrm{BMI} \geq 30 \mathrm{~kg} / \mathrm{m}^{2}$.

Results: Obese people had more elevated hsCRP levels than both their normal weight and overweight counterparts $(P=0.000$ and $P=0.000$, respectively). Similarly, serum concentrations of sCD40L were significantly higher, statistically, in obese subjects compared with normal weight subjects $(P=0.003)$. In addition, obese subjects had higher values of sCD40L than overweight subjects, but the difference did not reach statistical significance $(P=0.063)$. The levels of high-density lipoprotein cholesterol were significantly lower in obese subjects compared to normal weight subjects $(P=0.048)$. The analysis of platelet count disclosed a statistically significant difference between obese subjects and normal weight subjects $(P=0.028)$. The levels of $B M I$ were positively correlated with the serum levels of hsCRP and sCD40L in all subjects $(r=0.5 \mathrm{I}, P=0.000$ and $r=0.283, P=0.000$, respectively). Levels of hsCRP were positively correlated with waist circumference, fasting glucose, total cholesterol, triglyceride, low-density lipoprotein cholesterol, leukocytes, platelets, systolic and diastolic blood pressure. Similarly, soluble CD40L levels were positively correlated with waist circumference, fasting glucose and leukocytes.

Conclusion: Obese patients showed a significant increase of hsCRP and sCD40L levels compared with normal weight subjects, which might contribute to the known proinflammatory milieu found in these patients.

Keywords: Body mass index; CD40 ligand; C-reactive protein; Inflammation; Obesity

Corresponding Author: Ilkay Tugba Unek, MD; Dokuz Eylul University School of Medicine; Department of Internal Medicine; 35340, Inciralti; Izmir; Turkey; Tel: 00902324I2480I; Fax: 00902322772303; Email: tugba.gun@deu.edu.tr
Received: September 26, 2009 Ist Revision: January 22, 2010 2nd Revision: March 25, 2010 Accepted: March 25, 2010
Financial Support: This project was supported by the Dokuz Eylul University Research Foundation Accountancy (No:04.KB.SAĞ.095). 
besity has been suggested as an independent risk factor for cardiovascular disease. ${ }^{1,2}$ The levels of several acute phase response proteins and proinflammatory cytokines are significantly increased in both atherosclerosis and obesity. ${ }^{3}$ Adipose tissue is now recognized as an endocrine organ involved in regulating physiologic and pathologic processes including inflammation. It synthesizes and secretes a variety of products known as adipokines, including cytokines and chemokines. The release of adipokines such as tumor necrosis factor-alpha (TNF- $\alpha$ ), interleukin (IL)-6, and monocyte chemoattractant protein-1 (MCP-1) leads to a chronic subinflammatory state that could play a central role in the increased risk of cardiovascular disease associated with obesity. ${ }^{4-6}$

Serum high-sensitive C-reactive protein (hsCRP) is the principal mediator of the acute phase response. Previous studies have shown increased levels of CRP in patients with obesity. ${ }^{3,7-9}$ In addition, decrease in the levels of CRP after weight loss was reported in these patients. ${ }^{10-14}$ It has been reported that adipose tissue is an important determinant of a low level, chronic inflammatory state as reflected by levels of CRP. ${ }^{8}$

Besides the classical inflammatory markers, CD40 ligand (CD40L), being a trans-membrane protein and member of the tumor necrosis family, was introduced as a new inflammatory marker. It has been identified on T-helper cells, platelets and vascular smooth muscle cells. ${ }^{15}$ Studies on the cellular distribution of CD40L indicate that $>95 \%$ of the circulating CD40L exist in platelets. Platelets express CD40L on their surface upon stimulation; CD40L is then cleaved and circulates as soluble CD40L (sCD40L). When expressed on the surface of platelets and exposed to CD40-bearing vascular cells, platelet-associated CD40L triggers the expression of various proinflammatory mediators, such as intercellular adhesion molecule-1, vascular cell adhesion molecule-1, IL-1, IL-6, IL-8, IL-12, TNF- $\alpha$, interferon- $\gamma$, and MCP-1. ${ }^{16-18}$ During recent years the CD40-CD40L system has been implicated in the pathophysiology of chronic inflammatory diseases, including atherosclerosis. ${ }^{16-19}$ There is evidence that the $\mathrm{sCD} 40 \mathrm{~L}$ level is a strong predictor of cardiovascular risk. ${ }^{20}$ In literature, enhanced levels of CD40L were reported in patients with hypercholesterolemia, ${ }^{21-23}$ diabetes mellitus, ${ }^{24,25}$ and acute coronary syndromes. ${ }^{26-29}$ Few studies have reported the relationship between obesity and sCD40L. ${ }^{30-32}$ Therefore, our aim was to test whether obesity is associated with low-grade systemic inflammation as measured by serum hsCRP and sCD40L concentration.

\section{Methods}

Subjects

Patients were recruited from the Department of Internal Medicine at the Dokuz Eylul University Faculty of Medicine hospital. We enrolled 148 patients between the ages of 27 years and 80 years in the study. All subjects gave written informed consent, and the study protocol was approved by the Ethics Committee of Dokuz Eylul University. A standardized health questionnaire was completed by a physician covering the subjects' past medical history, current medications and information about other diseases. Height, weight, and waist and hip circumferences were recorded with subjects wearing light clothing without shoes. Body mass index (BMI) was calculated as the weight in kilograms divided by the height in meters squared. Waist circumference was measured at the natural indentation between the $10^{\text {th }}$ rib and the iliac crest (minimum waist). Hip circumference was measured over the widest part of the gluteal region, and the waist-to-hip ratio (WHR) was calculated. Arterial blood pressure was measured using a mercury sphygmomanometer on the right arm with the subjects in a sitting position after a 5 -minute rest.

The participants were divided into three groups depending upon their BMI: Group 1, BMI $<25 \mathrm{~kg} / \mathrm{m}^{2}(\mathrm{n}=30)$; Group 2, BMI $25 \mathrm{~kg} / \mathrm{m}^{2}$ to $29.9 \mathrm{~kg} / \mathrm{m}^{2}$ ( $\mathrm{n}=62$ ); and Group 3: BMI $\geq 30$ $\mathrm{kg} / \mathrm{m}^{2} \quad(\mathrm{n}=56)$. Obesity was defined as $\mathrm{BMI} \geq 30 \mathrm{~kg} / \mathrm{m}^{2}$. Subjects with BMI between $25 \mathrm{~kg} / \mathrm{m}^{2}$ and $29.9 \mathrm{~kg} / \mathrm{m}^{2}$ were accepted as overweight, and subjects with BMI smaller than $25 \mathrm{~kg} / \mathrm{m}^{2}$ were accepted as normal weight. Diabetes mellitus (DM), impaired glucose tolerance (IGT) and impaired fasting glucose (IFG) were defined according to the Report of the Expert Committee on the Diagnosis and Classification of Diabetes Mellitus. ${ }^{33}$ Subjects taking insulin or oral antidiabetic drugs were considered to have diabetes. The major exclusion criteria were DM, IGT, IFG, asthma/chronic obstructive pulmonary disease, chronic congestive heart failure, rheumatological disease, renal or hepatic dysfunction, cancer, and use of anti-inflammatory therapy or immunosuppressants.

\section{Blood Sampling and Assay}

Subjects underwent complete blood count and routine biochemical evaluations including fasting glucose (FG), postprandial glucose (PPG), total cholesterol (TC), lowdensity lipoprotein cholesterol (LDL-C), high-density lipoprotein cholesterol (HDL-C) and triglyceride (TG). All blood analyses were performed in a central laboratory. Serum TG, TC and HDL-C were measured on Roche Diagnostics Modular Analytics-DP analyzer (Roche Diagnostics, Tokyo, Japan) with the dedicated kits (Roche Diagnostics, Mannheim, Germany). Serum LDL-C concentrations were estimated according to the Friedewald formula at concentrations of triglyceride $<400 \mathrm{mg} / \mathrm{dL}$. The direct LDL-C analysis was performed on a Roche Diagnostics Modular Analytics-DP analyzer at concentrations of triglyceride $\geq 400 \mathrm{mg} / \mathrm{dL}$. Fasting venous blood samples $(10 \mathrm{~mL})$ were drawn from the antecubital vein into pyrogen-free blood collection tubes without any additives. All blood samples were collected under minimal tourniquet pressure. Blood samples were allowed to clot for 15 to 30 minutes, and were centrifuged at $1500 \mathrm{~g}$ and $4^{\circ} \mathrm{C}$ for 10 minutes. The serum was then separated and stored 
Table 1. Characteristics of study participants based upon BMI levels.

\begin{tabular}{|c|c|c|c|c|}
\hline Characteristic & Group 1 & Group 2 & Group 3 & $P$ \\
\hline \multicolumn{5}{|l|}{ Physical } \\
\hline Sex, M/F & $7 / 23$ & $15 / 47$ & $10 / 46$ & $0.683^{a}$ \\
\hline Age, y (mean $\pm S D)$ & $55.00 \pm 10.48$ & $53.53 \pm 10.07$ & $50.46 \pm 8.02$ & 0.070 \\
\hline $\mathrm{BMI}, \mathrm{kg} / \mathrm{m}^{2}(\mathrm{mean} \pm \mathrm{SD})$ & $22.44 \pm 1.94$ & $27.62 \pm 1.45$ & $35.26 \pm 4.23$ & 0.000 \\
\hline Smoking, n (\%) & $7(23)$ & $24(38)$ & $13(23)$ & $0.128^{a}$ \\
\hline HT, n (\%) & $18(60)$ & $36(58)$ & $49(87)$ & $0.001^{a}$ \\
\hline MS, n (\%) & $6(20)$ & $30(48)$ & $51(91)$ & $0.000^{\mathrm{b}}$ \\
\hline \multicolumn{5}{|l|}{ Waist, $\mathrm{cm}$} \\
\hline Female (mean $\pm S D)$ & $76.11 \pm 6.10$ & $85.99 \pm 6.37$ & $99.40 \pm 8.95$ & $0.000^{c}$ \\
\hline Male $($ mean $\pm S D)$ & $87.43 \pm 5.50$ & $96.43 \pm 7.46$ & $110.00 \pm 8.15$ & $0.000^{c}$ \\
\hline \multicolumn{5}{|l|}{ WHR } \\
\hline Female (mean+SD) & $0.82 \pm 0.13$ & $0.82 \pm 0.05$ & $0.85 \pm 0.08$ & $0.008^{c}$ \\
\hline Male $($ mean $\pm S D)$ & $0.89 \pm 0.05$ & $0.94 \pm 0.05$ & $0.97 \pm 0.06$ & $0.010^{c}$ \\
\hline \multicolumn{5}{|l|}{ Biochemical (mean $\pm S D)$} \\
\hline $\mathrm{SBP}, \mathrm{mmHg}$ & $122.83 \pm 13.63$ & $123.79 \pm 14.16$ & $128.48 \pm 12.54$ & 0.089 \\
\hline $\mathrm{DBP}, \mathrm{mmHg}$ & $78.17 \pm 7.37$ & $78.63 \pm 7.90$ & $83.04 \pm 8.40$ & 0.004 \\
\hline $\mathrm{FG}, \mathrm{mg} / \mathrm{dL}$ & $89.83 \pm 6.77$ & $91.61 \pm 7.41$ & $93.59 \pm 7.54$ & 0.070 \\
\hline $\mathrm{PPG}, \mathrm{mg} / \mathrm{dL}$ & $98.18 \pm 19.81$ & $104.11 \pm 16.48$ & $105.98 \pm 18.96$ & 0.302 \\
\hline $\mathrm{TC}, \mathrm{mg} / \mathrm{dL}$ & $197.93 \pm 29.36$ & $203.13 \pm 39.62$ & $206.71 \pm 38.12$ & 0.589 \\
\hline $\mathrm{TG}, \mathrm{mg} / \mathrm{dL}$ & $133.00 \pm 137.25$ & $144.50 \pm 103.40$ & $158.98 \pm 84.21$ & 0.523 \\
\hline LDL-C, mg/dL & $113.90 \pm 22.40$ & $118.42 \pm 34.45$ & $124.79 \pm 34.14$ & 0.297 \\
\hline HDL-C, mg/dL & $60.87 \pm 14.00$ & $56.87 \pm 16.95$ & $52.13 \pm 15.54$ & 0.045 \\
\hline WBC $\left(x 10^{3} / \mu \mathrm{L}\right)$ & $6.82 \pm 1.73$ & $7.11 \pm 2.08$ & $7.52 \pm 1.88$ & 0.273 \\
\hline Platelets $\left(\times 10^{3} / \mu \mathrm{L}\right)$ & $246.07 \pm 64.49$ & $263.05 \pm 59.32$ & $287.98 \pm 75.77$ & 0.022 \\
\hline MPV, fL & $8.47 \pm 1.13$ & $8.53 \pm 1.04$ & $8.51 \pm 1.06$ & 0.970 \\
\hline hsCRP, mg/L & $1.38 \pm 1.07$ & $2.53 \pm 2.28$ & $4.61 \pm 3.85$ & 0.000 \\
\hline sCD40L, ng/ml & $0.38 \pm 0.50$ & $0.62 \pm 0.53$ & $0.94 \pm 1.01$ & 0.003 \\
\hline
\end{tabular}

Group 1, BMl<25 kg/m²; Group 2, BMI 25-29.9 kg/m²; Group 3, BMl>30 kg/m².

BMI: body mass index; HT: hypertension; MS: metabolic syndrome; WHR: waist-to-hip ratio; SBP: systolic blood pressure; DBP: diastolic blood pressure; FG: fasting glucose; PPG: postprandial glucose; TC: total cholesterol; TG: triglyceride; LDL-C: low density lipoprotein cholesterol; HDL-C: high density lipoprotein cholesterol; WBC: white blood cell; MPV: mean platelet volume; hsCRP: high-sensitivity C-reactive protein; sCD40L: soluble CD40 ligand; SD: standard deviation; $P$ : $P$ value.

${ }^{\mathrm{a}} \mathrm{Chi}-\mathrm{Square}$; ${ }^{\mathrm{C}} \mathrm{Chi}$-Square for linear trend; ${ }^{\mathrm{c}}$ Kruskal-Wallis.

at $-20^{\circ} \mathrm{C}$ until analysis. Samples were thawed only once. Serum sCD40L concentrations were determined using an enzyme linked immunosorbent assay (ELISA) kit from Biosource (Bender MedSystems Human sCD40L Instant ELISA). The intra-assay and interassay coefficients of variation for $\mathrm{sCD} 40 \mathrm{~L}$ were $5.00 \%$ and $6.20 \%$, respectively, with a sensitivity of $0.062 \mathrm{ng} / \mathrm{mL}$, according to the manufacturer. Analysis of hsCRP was performed on a Cobas Integra 400 Plus analyzer (Roche Diagnostics, Rotkreuz, Switzerland) based on particle-enhanced turbidimetry (CRPLX, Roche Diagnostics, Mannheim, Germany) with a detection limit of $0.085 \mathrm{mg} / \mathrm{L}$ and an extended measuring range of $0.085 \mathrm{mg} / \mathrm{L}$ to $1600 \mathrm{mg} / \mathrm{L}$ (with auto-rerun), according to the manufacturer.

\section{Statistical Analysis}

All statistical analyses were performed with an SPSS program for Windows (version 11.0). Means and proportions for baseline variables were compared between groups using Correlation test, multiple linear regression analysis, ANOVA for continuous variables, and nonparametric Kruskal-Wallis with Bonferronni's correction. Differences in categorical variables were measured by Chi-Square test and Chi-Square for linear trend test. All data of continuous variables were expressed as mean $\pm \mathrm{SD} ; P$ values of 0.05 or less were considered to be statistically significant.

\section{Results}

The clinical and biochemical characteristics of the 148 nondiabetic subjects, aged 27 to 80 years, are summarized in table 1 . The rate of patients with hypertension in the obese group was significantly higher, statistically, when compared with normal weight and overweight subjects. The means of FG, PPG, TC, TG, LDL and leukocyte count were the highest in obese subjects and the lowest in normal weight subjects, but the difference did not reach statistical significance. The levels of HDL-C were significantly lower in obese subjects compared to normal weight subjects $(P=0.048)$. The analysis of platelet count disclosed a statistically significant difference between obese subjects and normal weight subjects $(P=0.028)$. However, platelet count in overweight subjects was not significantly different when compared with normal weight $(P=0.831)$ and obese subjects $(P=0.157)$.

We compared serum concentrations of hsCRP (figure 1) and sCD40L (figure 2) among three BMI groups. Obese patients 


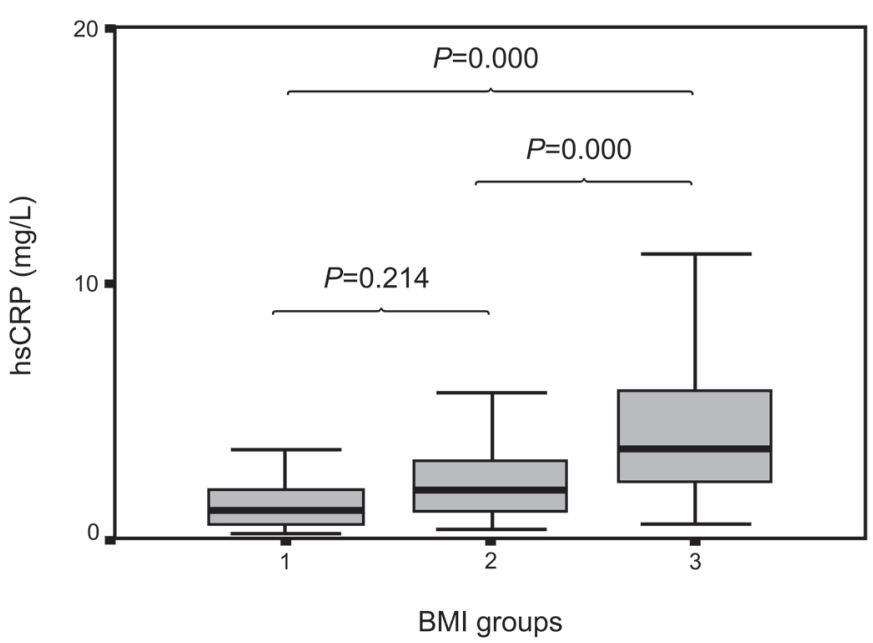

Figure 1. Increasing hsCRP values in relation to BMI groups.

had more elevated hsCRP levels than both their normal weight and overweight counterparts $(P=0.000$ and $P=0.000$, respectively). Similarly, serum concentrations of $\mathrm{SCD}^{\mathrm{N}} \mathrm{CL}$ were significantly higher, statistically, in obese subjects compared with normal weight subjects $(P=0.003)$. In addition, obese subjects had higher values of sCD40L than overweight subjects, but the difference did not reach statistical significance $(P=0.063)$.

The levels of BMI were positively correlated with waist circumference, systolic blood pressure (SBP), diastolic blood pressure (DBP), FG, white blood cell count (WBC) and platelets, and negatively correlated with age and HDL-C (table 2). Levels of hsCRP were positively correlated with BMI, waist circumference, SBP, DBP, FG, TC, TG, LDL-C, WBC and platelets. Similarly, soluble CD40L levels were positively correlated with BMI, waist circumference, FG and WBC (table 2). In a multiple linear regression analysis, hsCRP was correlated with BMI, LDL-C and WBC, and sCD40L was correlated with BMI and WBC (table 3).

\section{Discussion}

In the present study, we have confirmed significantly higher levels of hsCRP and sCD40L in obese patients compared with normal weight subjects. In the literature, data about the relationship between obesity and $\mathrm{sCD} 40 \mathrm{~L}$ is limited. ${ }^{30-32}$ Guldiken et al $^{32}$ reported significantly higher values of sCD40L in patients with severe obesity $\left(B M I \geq 35 \mathrm{~kg} / \mathrm{m}^{2}\right)$ compared to obese patients (BMI $30-34.9 \mathrm{~kg} / \mathrm{m}^{2}$ ) and nonobese subjects $\left(\mathrm{BMI}<25 \mathrm{~kg} / \mathrm{m}^{2}\right)$. They did not detect a significant difference between the obese and non-obese groups in terms of mean sCD40L levels. However, in our study we found significantly higher levels of $\mathrm{sCD} 40 \mathrm{~L}$ in obese patients compared with normal weight subjects. This finding is consistent with the previous studies demonstrating that the sCD40L levels are elevated in obese people and decrease after weight loss. ${ }^{30-31}$ In this study, we have demonstrated positive correlations between BMI and both hsCRP and sCD40L levels. In addition, higher waist circumferences, indicative of a large amount of abdominal visceral fat, were associated with higher hsCRP and sCD40L concentrations. A possible mechanism for the observed association may be the production of several cytokines by adipose tissue. For example, IL-6 production by adipocytes is the main hepatic stimulus for CRP synthesis. ${ }^{8}$ In this study, the levels of the two inflammatory markers correlate directly with the measurements of obesity (BMI and waist circumference). In this context, increased hsCRP and sCD40L levels in obesity may explain further the relationship between obesity and inflammation. Previous studies have reported a positive association between BMI and CRP concentration. 3,8-12,34-36 Low-grade systemic inflammation has been shown to increase the risk for cardiovascular disease. A number of epidemiological studies have shown that CRP is an important risk factor for atherosclerosis and coronary heart disease. ${ }^{12,37-42}$ Recent studies suggest that $\mathrm{sCD} 40 \mathrm{~L}$ plays a pathogenetic role in atherothrombotic complications in cardiovascular disease. ${ }^{16-19}$ The role of CD40L in atherogenesis is confirmed by the fact that in hyperlipidemic mice anti-CD40L antibodies reduced atherosclerotic lesions. ${ }^{43}$ Some of the increased risk for cardiovascular disease in obese patients may be explained by our observation that increased CRP and $\mathrm{sCD} 40 \mathrm{~L}$ concentrations are more prevalent in these patients.

Desideri et $\mathrm{al}^{30}$ reported that $\mathrm{sCD} 40 \mathrm{~L}$ was not only correlated with BMI in adults, but was also more strongly related to lipid peroxidation. Consistent with this study, we found a significant correlation between the levels of sCD40L and BMI. Lipid peroxidation, a marker of oxidative injury, was not measured in our study, but it is well known that oxidative stress is increased in obesity, which might relate to the dysregulated production of adipocytokines. 44 Circulating sCD40L was believed to derive predominantly from platelets. ${ }^{17}$ It has been reported that obesity is associated with platelet activation and lipid peroxidation. ${ }^{45}$ In this context, the majority of the increased sCD40L in obesity should originate from activated platelets. The mechanism accounting for CD40L expression

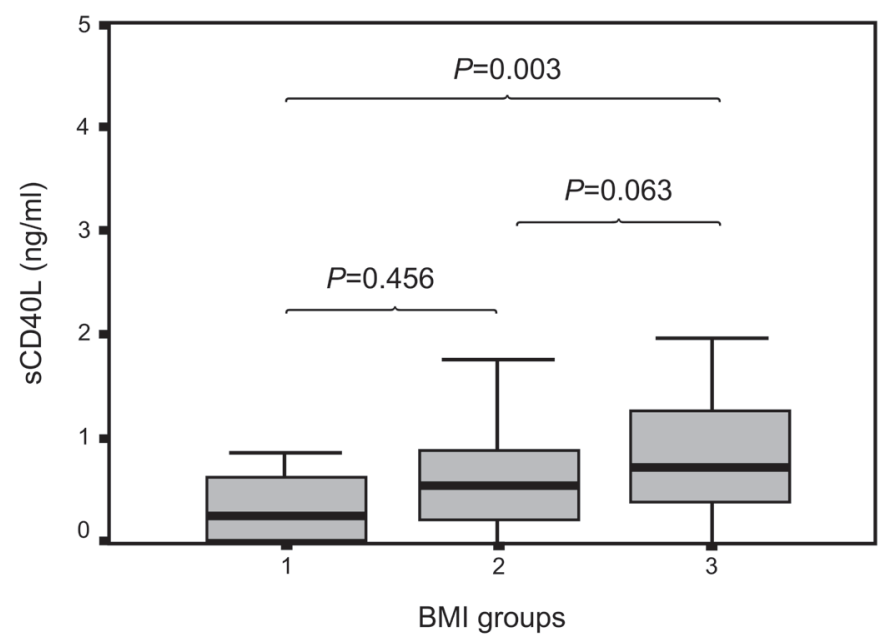

Figure 2. Increasing SCD40L values in relation to BMI groups. 
Table 2: Pearson correlation test between $\mathrm{BMI} / \mathrm{hsCRP} / \mathrm{SCD} 40 \mathrm{~L}$ and all other characteristics evaluated.

\begin{tabular}{|c|c|c|c|c|c|c|}
\hline \multirow{2}{*}{ Characteristic } & \multicolumn{2}{|c|}{ BMI } & \multicolumn{2}{|c|}{ hsCRP } & \multicolumn{2}{|c|}{ sCD40L } \\
\hline & $r$ & $P$ & $r$ & $\boldsymbol{P}$ & $r$ & $P$ \\
\hline \multicolumn{7}{|l|}{ Physical } \\
\hline Age (y) & -0.246 & 0.003 & -0.062 & 0.458 & -0.067 & 0.421 \\
\hline BMI $\left(\mathrm{kg} / \mathrm{m}^{2}\right)$ & - & - & 0.514 & 0.000 & 0.283 & 0.000 \\
\hline Waist (cm) & 0.782 & 0.000 & 0.400 & 0.000 & 0.239 & 0.003 \\
\hline WHR & 0.086 & 0.297 & 0.059 & 0.479 & 0.053 & 0.520 \\
\hline \multicolumn{7}{|l|}{ Biochemical } \\
\hline $\mathrm{SBP}(\mathrm{mmHg})$ & 0.178 & 0.030 & 0.170 & 0.038 & 0.067 & 0.418 \\
\hline DBP $(\mathrm{mmHg})$ & 0.259 & 0.002 & 0.212 & 0.010 & -0.018 & 0.830 \\
\hline $\mathrm{FG}(\mathrm{mg} / \mathrm{dL})$ & 0.244 & 0.003 & 0.164 & 0.046 & 0.168 & 0.042 \\
\hline PPG (mg/dL) & 0.157 & 0.082 & 0.171 & 0.058 & -0.047 & 0.608 \\
\hline $\mathrm{TC}(\mathrm{mg} / \mathrm{dL})$ & 0.086 & 0.303 & 0.173 & 0.037 & 0.084 & 0.311 \\
\hline TG (mg/dL) & 0.136 & 0.100 & 0.194 & 0.018 & 0.082 & 0.321 \\
\hline LDL-C (mg/dL) & 0.124 & 0.133 & 0.176 & 0.032 & 0.085 & 0.307 \\
\hline HDL-C (mg/dL) & -0.224 & 0.000 & -0.158 & 0.055 & -0.082 & 0.321 \\
\hline 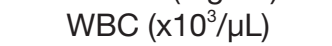 & 0.185 & 0.030 & 0.211 & 0.013 & 0.189 & 0.026 \\
\hline Platelets $\left(x 10^{3} / \mu \mathrm{L}\right)$ & 0.259 & 0.002 & 0.217 & 0.011 & 0.126 & 0.141 \\
\hline MPV (fL) & -0.035 & 0.709 & -0.057 & 0.542 & -0.010 & 0.919 \\
\hline hsCRP (mg/L) & 0.514 & 0.000 & - & - & 0.090 & 0.278 \\
\hline sCD40L (ng/ml) & 0.283 & 0.000 & 0.090 & 0.278 & - & - \\
\hline
\end{tabular}

r: Pearson's product-moment correlation coefficient; $P$ : $P$ value; BMI: body mass index; WHR: waist-to-hip ratio; SBP: systolic blood pressure; DBP: diastolic blood pressure; FG: fasting glucose; PPG: postprandial glucose; TC: total cholesterol; TG: triglyceride; LDL-C: low density lipoprotein cholesterol; HDL-C: high density lipoprotein cholesterol; WBC: white blood cell; MPV: mean platelet volume; hsCRP: high-sensitivity C-reactive protein; sCD40L: soluble CD40 ligand.

by activated platelets is still unclear, but Pignatelli et al ${ }^{46}$ showed that superoxide anion production plays a key role in platelet CD40L expression. The fact that oxidative stress also plays a role in platelet CD40L expression suggests that an increase in CD40L expression might be another mechanism through which oxidative stress elicits atherosclerotic damage. 46

It was reported that obese people had elevated platelet counts. 7,47 Similarly, we observed significantly increased platelet counts in obese people when compared to normal weight people. This finding suggests that the increased sCD40L level might be a result of the increased platelet count in obese people. Mean platelet volume (MPV), a determinant of platelet function, is a newly emerging risk factor for atherothrombosis. A positive correlation was reported between the levels of MPV and BMI in obese people. ${ }^{48}$

The levels of WBC, hsCRP, sCD40L were found to correlate with the levels of BMI in all subjects. The mean WBC level, which is another marker of inflammation, was highest in obese people and lowest in normal-weight people. In all subjects, both hsCRP and sCD40L levels were positively correlated to WBC. Our data support the opinion that obesity is a chronic subclinical inflammatory disease as reflected by levels of WBC, hsCRP and sCD40L. 7,8,49,50 The association of leukocyte count with BMI, hsCRP and sCD40L suggests that the leukocyte count may be of clinical value as a marker of low-grade systemic inflammation in obese patients. The leukocyte count has been reported previously as a marker of

Table 3. Stepwise multiple regression analysis with hsCRP and SCD40L.

\begin{tabular}{lcccc}
\hline Variable & B & SE & Coefficient $\beta$ & P \\
\hline hsCRP & & & & 0.000 \\
Constant & -7.41 & 1.57 & 0.45 & 0.000 \\
BMl & 0.24 & 0.04 & 0.14 & 0.055 \\
LDL-C & 0.01 & 0.01 & 0.14 & 0.066 \\
WBC & 0.22 & 0.12 & & 0.055 \\
sCD 4 OL & & & 0.26 & 0.002 \\
Constant & -0.71 & 0.37 & 0.14 & 0.091 \\
BMI & 0.03 & 0.01 & 0.03 & \\
WBC & 0.06 & & & \\
\end{tabular}

B: regression coefficient; SE: Standard error; Coefficient $\beta$ : standardized regression coefficient; $P$ : $P$-value; BMI: body mass index; LDL-C: low density lipoprotein cholesterol; WBC: white blood cell; hsCRP: high-sensitivity C-reactive protein; sCD40L: soluble CD40 ligand. 
inflammation and cardiovascular disease risk. ${ }^{51,52}$ Other variables positively correlated to BMI in the present study were SBP, DBP, FG, and negatively with HDL-C. Our data support the previous reports indicating that obesity is a chronic metabolic disorder with increased cardiovascular risk factors such as dyslipidemia, hypertension, inflammatory markers, and the prothrombotic state. ${ }^{53}$

\section{Conclusion}

In our study, obese patients showed a significant increase of hsCRP and sCD40L levels compared with normal weight subjects, which might contribute to the known proinflammatory milieu found in these patients. Because inflammatory markers may be directly involved in atherogenesis, these results suggest an important mechanism through which obesity might affect the risk of cardiovascular disease.

\section{References}

1. McLaughlin T, Allison G, Abbasi F, Lamendola C, Reaven G. Prevalence of insulin resistance and associated cardiovascular disease risk factors among normal weight, overweight, and obese individuals. Metabolism 2004;53:495-499.

2. Kopelman PG. Obesity as a medical problem. Nature 2000;404:635-643.

3. Piché ME, Lemieux S, Weisnagel SJ, Corneau L, Nadeau A, Bergeron J. Relation of high-sensitivity C-reactive protein, interleukin-6, tumor necrosis factor-alpha, and fibrinogen to abdominal adipose tissue, blood pressure, and cholesterol and triglyceride levels in healthy postmenopausal women. Am J Cardiol 2005;96:92-97.

4. Antuna-Puente B, Feve B, Fellahi S, Bastard JP. [Obesity, inflammation and insulin resistance: which role for adipokines.] [Article in French] Therapie 2007;62:285-292.

5. Antuna-Puente B, Feve B, Fellahi S, Bastard JP. Adipokines: the missing link between insulin resistance and obesity. Diabetes Metab 2008;34:2-11.

6. Mohamed-Ali V, Pinkey JH, Coppack SW. Adipose tissue as an endocrine and paracrine organ. Int J Obes Relat Metab Disord 1998;22:1145-1158.

7. Flores-Alfaro E, Parra-Rojas I, Salgado-Bernabé AB, ChávezMaldonado JP, Salazar-Martinez E. Cardiovascular risk evaluated by C-reactive protein levels in diabetic and obese Mexican subjects. Circ J 2008;72:1170-1174.

8. Yudkin JS, Stehouwer CD, Emeis JJ, Coppack SW. C-reactive protein in healthy subjects: associations with obesity, insulin resistance, and endothelial dysfunction: role for cytokines originating from adipose tissue? Arterioscler Thromb Vasc Biol 1999;19:972-978.

9. Visser M, Bouter LM, McQuillan GM, Wener MH, Harris TB. Elevated C-reactive protein levels in overweight and obese adults. JAMA 1999;282:2131-2135.

10. Hak AE, Stehouwer CD, Bots ML, Polderman KH, Schalkwijk CG, Westendorp IC, Hofman A, Witteman JC. Associations of C-reactive protein with measures of obesity, insulin resistance, and subclinical atherosclerosis in healthy, middleaged women. Arterioscler Thromb Vasc Biol 1999;19: 1986-1991.

11. Esposito K, Pontillo A, Di Palo C, Giugliano G, Masella M, Marfella R, Giugliano D. Effect of weight loss and lifestyle changes on vascular inflammatory markers in obese women: a randomized trial. JAMA 2003;289:1799-1804.
12. Koenig W, Sund M, Fröhlich M, Fischer HG, Löwel H, Döring A, Hutchinson WL, Pepys MB. C-Reactive protein, a sensitive marker of inflammation, predicts future risk of coronary heart disease in initially healthy middle-aged men: results from the MONICA (Monitoring Trends and Determinants in Cardiovascular Disease) Augsburg Cohort Study, 1984 to 1992. Circulation 1999;99:237-242.

13. McLaughlin T, Abbasi F, Lamendola C, Liang L, Reaven G, Schaaf P, Reaven P. Differentiation between obesity and insulin resistance in the association with C-reactive protein. Circulation 2002;106:2908-2912.

14. Haffner SM. Insulin resistance, inflammation, and prediabetic state. Am J Cardiol 2003;92:18J-26J.

15. Schönbeck U, Libby P. The CD40/CD154 receptor/ligand dyad. Cell Mol Life Sci 2001;58:4-43.

16. Schönbeck U, Mach F, Libby P. CD154 (CD40 ligand). Int J Biochem Cell Biol 2000;32:687-693.

17. André P, Nannizzi-Alaimo L, Prasad SK, Phillips DR. Plateletderived CD40L: the switch-hitting player of cardiovascular disease. Circulation 2002;106:896-899.

18. Schönbeck U, Libby P. CD40 signaling and plaque instability. Circ Res 2001;89:1092-1103.

19. Phipps RP. Atherosclerosis: The emerging role of inflammation and the CD40-CD40 ligand system. Proc Natl Acad Sci USA 2000;97:6930-6932.

20. Schönbeck U, Varo N, Libby P, Buring J, Ridker PM. Soluble CD40L and cardiovascular risk in women. Circulation 2001;104:2266-2268.

21. Garlichs CD, John S, Schmeisser A, Eskafi S, Stumpf C, Karl M, Goppelt-Struebe M, Schmieder R, Daniel WG. Upregulation of CD40 and CD40 Ligand (CD154) in patients with moderate hypercholesterolemia. Circulation 2001;104:2395-2400.

22. Cipollone F, Mezzetti A, Porreca E, Di Febbo C, Nutini M, Fazia M, Falco A. Association between enhanced soluble CD40L and prothrombotic state in hypercholesterolemia: effects of statin therapy. Circulation 2002;106:399-402.

23. Semb AG, van Wissen S, Ueland T, Smilde T, Waehre T, Tripp MD, Froland SS, Kastelein JJ, Gullestad L, Pedersen TR, Aukrust P, Stalenhoef AF. Raised serum levels of soluble CD40 ligand in patients with familial hypercholesterolemia: downregulatory effect of statin therapy. J Am Coll Cardiol 2003;41:275-279.

24. Jinchuan Y, Zonggui W, Jinming C, Li L, Xiantao K. Upregulation of CD40-CD40 ligand system in patients with diabetes mellitus. Clinica Chim Acta 2004;339:85-90.

25. Varo N, Vicent D, Libby P, Nuzzo R, Calle-Pascual AL, Bernal MR, Fernández-Cruz A, Veves A, Jarolim P, Varo JJ, Goldfine A, Horton E, Schönbeck U. Elevated plasma levels of the atherogenic mediator soluble CD40 ligand in diabetic patients: a novel target of thiazolidinediones. Circulation 2003;107:2664-2669.

26. Aukrust P, Müller F, Ueland T, Berget T, Aaser E, Brunsvig A, Solum NO, Forfang K, Frøland SS, Gullestad L. Enhanced levels of soluble and membrane-bound CD40 ligand in patients with unstable angina. Possible reflection of $\mathrm{T}$ lymphocyte and platelet involvement in the pathogenesis of acute coronary syndromes. Circulation 1999;100:614-620.

27. Varo N, de Lemos JA, Libby P, Morrow DA, Murphy SA, Nuzzo R, Gibson CM, Cannon CP, Braunwald E, Schönbeck U. Soluble CD40L: risk prediction after acute coronary syndromes. Circulation 2003;108:1049-1052.

28. Garlichs CD, Eskafi S, Raaz D, Schmidt A, Ludwig J, Herrmann M, Klinghammer L, Daniel WG, Schmeisser A. Patients with acute coronary syndromes express enhanced CD40 ligand/CD154 on platelets. Heart 2001;86:649-655. 
29. Peng DQ, Zhao SP, Li YF, Li J, Zhou HN. Elevated soluble CD40 ligand is related to the endothelial adhesion molecules in patients with acute coronary syndrome. Clinica Chim Acta 2002;319:19-26.

30. Desideri G, Feri C. Effects of obesity and weight loss on soluble CD40L levels. JAMA 2003;289:1781-1782.

31. Schernthaner GH, Kopp HP, Krzyzanowska K, Kriwanek S, Koppensteiner R, Schernthaner G. Soluble CD40L in patients with morbid obesity: significant reduction after bariatric surgery. Eur J Clin Invest 2006;36:395-401.

32. Guldiken S, Demir M, Arikan E, Turgut B, Azcan S, Gerenli M, Tugrul A. The levels of circulating markers of atherosclerosis and inflammation in subjects with different degrees of body mass index: Soluble CD40 ligand and high-sensitivity C-reactive protein. Thromb Res 2007;119:79-84.

33. Genuth S, Alberti KG, Bennett P, Buse J, Defronzo R, Kahn R, Kitzmiller J, Knowler WC, Lebovitz H, Lernmark A, Nathan D, Palmer J, Rizza R, Saudek C, Shaw J, Steffes M, Stern M, Tuomilehto J, Zimmet P; Expert Committee on the Diagnosis and Classification of Diabetes Mellitus. Follow-up report on the diagnosis of diabetes mellitus. Diabetes Care 2003;26:3160-3167.

34. Mendall MA, Patel P, Ballam L, Strachan D, Northfield TC. C reactive protein and its relation to cardiovascular risk factors: a population based cross sectional study. BMJ 1996;312:1061-1065.

35. Pieroni L, Bastard JP, Piton A, Khalil L, Hainque B, Jardel C. Interpretation of circulating C-reactive protein levels in adults: body mass index and gender are a must. Diabetes Metab 2003;29:133-138.

36. Festa A, D'Agastino R Jr, Williams K, Karter AJ, Mayer-Davis EJ, Tracy RP, Haffner SM. The relation of body fat mass and distribution to markers of chronic inflammation. Int J Obes Relat Metab Disord 2001;25:1407-1415.

37. Haverkate F, Thompson SG, Pyke SD, Gallimore JR, Pepys $\mathrm{MB}$. Production of C-reactive protein and risk of coronary events in stable angina. European Concerted Action on Thrombosis and Disabilities Angina Pectoris Study Group. Lancet 1997;349:462-466.

38. Pradhan AD, Ridker PM. Do atherosclerosis and type 2 diabetes share a common inflammatory basis? Eur Heart J 2002;23:831-834.

39. Yeh ET, Anderson HV, Pasceri V, Willerson JT. C-reactive protein: linking inflammation to cardiovascular complications. Circulation 2001;104:974-975.

40. Pasceri V, Willerson JT, Yeh ET. Direct proinflammatory effect of C-reactive protein on human endothelial cells. Circulation 2000;102:2165-2168.

41. Ridker PM, Hennekens CH, Buring JE, Rifai N. C-reactive protein and other markers of inflammation in the prediction of cardiovascular disease in women. N Engl J Med 2000;342:836-843.

42. Ridker PM, Buring JE, Cook NR, Rifai N. C-Reactive protein, the metabolic syndrome, and risk of incident cardiovascular events: an 8-year follow-up of 14719 initially healthy American women. Circulation 2003;107:391-397.

43. Mach F, Schönbeck U, Sukhova GK, Atkinson E, Libby P. Reduction of atherosclerosis in mice by inhibition of CD40 signalling. Nature 1998;394:200-203.

44. Furukawa S, Fujita T, Shimabukuro M, Iwaki M, Yamada Y, Nakajima Y, Nakayama O, Makishima M, Matsuda M, Shimomura L. Increased oxidative stress in obesity and its impact on metabolic syndrome. J Clin Invest 2004;114: 1752-1761.

45. Davi G, Guagnano MT, Ciabattoni G, Basili S, Falco A, Marinopiccoli M, Nutini M, Sensi S, Patrono C. Platelet activation in obese women: role of inflammation and oxidant stress. JAMA 2002;288:2008-2014.
46. Pignatelli P, Sanguigni V, Lenti L, Ferro D, Finocchi A, Rossi P, Violi F. gp91phox-dependent expression of platelet CD40 ligand. Circulation 2004;110:1326-1329.

47. Foschini D, Santos RV, Prado WL, de Piano A, Lofrano MC, Martins AC, Carnier J, Caranti DA, Sanches Pde L, Tock L, Mello MT, Tufik S, Dâmaso AR. Platelet and leptin in obese adolescents. J Pediatr (Rio J) 2008;84:516-521.

48. Coban E, Ozdogan M, Yazicioglu G, Akcit F. The mean platelet volume in patients with obesity. Int J Clin Pract 2005;59: 981-982.

49. Fernandez-Real JM, Ricart W. Insulin resistance and chronic cardiovascular inflammatory syndrome. Endocr Rev 2003;24:278-301.

50. Angelico F, Alessandri C, Ferro D, Pignatelli P, Del Ben M, Fiorello S, Cangemi R, Loffredo L, Violi F. Enhanced soluble CD40L in patients with the metabolic syndrome: Relationship with in vivo thrombin generation. Diabetologia 2006;49:1169-1174.

51. Baron HV, Cannon CP, Murphy SA, Braunwald E, Gibson CM. Association between white blood cell count, epicardial blood flow, myocardial perfusion, and clinical outcomes in the setting of acute myocardial infarction: a thrombolysis in myocardial infarction 10 substudy. Circulation 2000;102:2329-2334.

52. Yip HK, Wu CJ, Hang CL, Chang HW, Yang CH, Hsieh YK, Fang CY, Fu M, Yeh KH, Chen MC. Levels and values of inflammatory markers in patients with angina pectoris. Int Heart J 2005;46:571-581.

53. Poirier P, Eckel RH. Obesity and cardiovascular disease. Curr Atheroscler Rep 2002;4:448-453.

\section{Author Affiliations}

Ilkay Tugba Unek, MD*; Firat Bayraktar, MD $\%$; Dilek Solmaz, MD*; Hulya Ellidokuz, MDł; Ali Riza Sisman, MD§; Faize Yuksel\#; Sena Yesil, MD†

*Department of Internal Medicine, $\dagger$ Division of Endocrinology and Metabolism, $\ddagger$ Department of Public Health, $\S$ Department of Biochemistry, \#Division of Hematology, Dokuz Eylul University School of Medicine, Izmir, Turkey 